\title{
ESO's 10 per cent solution for Chile's astronomers
}

Munich. Much sooner than expected, Chilean astronomers have won their claims for more observing time on the European Southern Observatory (ESO) telescopes at $\mathrm{La}$ Silla in Chile. They are also likely to win better pay and working conditions.

Faced with a serious threat to plans for the DM570 million (US\$350 million) Very Large Telescope (VLT) at a second site in northern Chile, ESO has comprehensively backed down from its intransigent position based on a treaty signed nearly 20 years ago.

For the past few years, astronomers in Chile have been demanding guaranteed observation time in recognition of their role in hosting the telescopes. They also wanted pay parity with European scientists and technicians.

Sensitive to what it considered imperialistic attitudes on the part of the Europeans, the Chilean government backed the demands, and early this year called for ESO to renegotiate its 1964 contract. One counter in the discussion was the threat that Chile would withdraw cooperation over the 700 square km VLT site at Mount Paranal (see Nature 363, 384; 1993).

Although Chile had set a deadline at the beginning of September, four days of negotiations at the end of June have already produced an agreement that satisfies both sides. Chile has in principle won all its points, but ESO is relieved and happy to have, in exchange, a guaranteed future for its VLT project.

Provided that proposals are assessed as scientifically acceptable, scientists associated with Chilean institutes will now be guaranteed 10 per cent of observing time (what they had asked for) at each of the ESO telescopes at La Silla. Observing time is a valuable currency among astronomers, and there is a hefty waiting list; the telescopes are, on average, three times oversubscribed.

One side-effect of the agreement is that it is likely to encourage European astronomers to form scientific collaborations with Chileans to try to jump the queue, which ESO's spokesman Richard West says may be "no bad thing". The agreement also allocates 5 per cent of viewing time of the VLT to Chilean institutes.

The Chilean government says it will also play its part in helping to develop astronomy in Chile by giving more financial support to the training of Chilean astronomers and to astronomy research. ESO's major argument against giving guaranteed observing time was that there were simply not enough highly trained Chileans to make use of it.

The new agreements are expected to be rubber-stamped at ESO's next council meeting in December.

Alison Abbott

\section{Science faces new treatment in British courts}

London. A radical overhaul of the way that science is used in British judicial proceedings has been proposed by the Royal Commission on Criminal Justice, which last week published the results of a two-year inquiry into the legal system in England and Wales.

The commission was set up by the government after several convictions by British courts in the 1970s were judged by the appeal court to be "unsafe", on some occasions because the convictions were based on forensic evidence later acknowledged to be flawed. That explains the attention paid by the commission to bridging the gulf between scientific and legal approaches to questions about the validity of evidence.

In particular, the commission suggests that where forensic science experts are due to appear for both sides of a disputed case, they should meet before the trial - if necessary in a formal hearing presided over by a judge - to work out points of agreement and disagreement. The goal would be to reduce the complexities of scientific arguments subsequently laid out before a jury.

Experts appearing in the witness box should not, as at present, be confined to answering questions put to them by lawyers for either side, says the commission. Rather, they should be given the opportunity to volunteer additional information they consider appropriate to the case being tried, a response to long-standing complaints by forensic scientists that their skills are often badly used in court proceedings.

A new Forensic Science Advisory Council should also be set up. This would have broad-ranging responsibilities, including the supervision of the quality of forensic investigations by both public and private laboratories and the encouragement of universitybased courses and research programmes.

But the commission throws cold water on the idea that the Home Office's Forensic Science Service (FSS), the main source of forensic evidence in court cases, should be hived off as an independent commercial organization - an avenue currently being explored by the government following its recent white paper on science. The commission says there is no evidence that the FSS would operate more effectively if it were cut off entirely from the Home Office, a conclusion welcomed by scientists working for the FSS, who fear that privatization could threaten their reputation for impartiality.

The commission acknowledges that the FSS has now corrected the shortcomings that led to a number of notorious miscarriages of justice in the 1970s. (One of these was the conviction of six Irishmen for allegedly bombing a pub in Birmingham, largely on the basis of scientific evidence, later discredited, that two of them had been handling nitroglycerine; the chromatographic test developed for the purpose proved less specific than supposed.)

But the 11 members of the commission suggest that further changes are still needed, given the number of cases in which scientific evidence plays a key role, as well as evidence that a substantial proportion of jury members ( 10 per cent in one survey) find scientific arguments difficult to follow.

This general move to tighten up the quality and use of scientific evidence has been widely welcomed in the legal community (in contrast to other more controversial proposals in the report, such as limiting a defendant's right to trial by jury). Indeed many of its specific proposals - for example that public sector forensic science laboratories should be made more accessible to defence lawyers - echo suggestions made earlier this year by the House of Lords Select Committee on Science and Technology.

But concerns still remain. Some lawyers argue that the proposals do not go far enough, and that the commission could have taken bolder steps to make forensic science expertise readily available to the defence, for example by recommending the creation of independent forensic science centres with this explicit responsibility.

Others warn that pre-trial hearings, by disclosing to the prosecution the detailed arguments likely to be used in challenging scientific evidence, will require defence lawyers to alert the prosecution to their line of attack - and thus reduce the chances of this attack succeeding in front of a jury.

And there still remains the question of how the government will respond to the commission's proposals, in particular those requiring the Treasury to provide extra funding. The royal commission, for example, backs the suggestion of the House of Lords committee that universities should be encouraged to carry out more forensic science research. It refers explicitly to the contribution of DNA profiling, and suggests that "a number of important forensic problems may be amenable to research, which might in consequence narrow the range of possible disputes between prosecution and defence".

In its earlier reply to the House of Lords, however, the government rejected a suggestion that it should provide more money earmarked for this purpose. Arguing that forensic science is not a scientific discipline in itself, but draws on developments in many areas of research, it suggested that applied research was best undertaken in organizations actively engaged in forensic work, and "funded by those who benefit directly".

David Dickson 